\title{
Correlates of Nigerian Polytechnic Students' Self-Communication in Study Reading
}

\author{
OLAJIDE, Joseph Lekan (Ph.D) FADARE, Babatunde Olusola \\ OLATIPE, Stephen Olabisi ADEDEJI, Thompson Okunola \\ Department of General Studies, Osun State College of Technology, Esa-Oke, Nigeria
}

\begin{abstract}
The primary responsibility of a student is to study if he is to attain the high standard in his course. The University of Manchester (2001) released a student's study reading plan which requested them to engage in one study activity or the other everyday including weekends. One effective way to exhibit and demonstrate such intensive study reading exercise is through the practice of self-communication. Using Ruesch and Bateson's (2016) seven traits of intrapersonal communication, this study investigated students' display of selfcommunication traits before and during examination. The Self Communication Questionnaire was administered on four hundred randomly selected students from four polytechnics. Results showed lower practice of, an insignificant correlation of, and a significant difference between, self communication displays associated with study reading before and during examination $(r=.46 ; t(399)=-6.851 ; \mathrm{p}<.05)$. The study concluded that students delayed study reading till examinations were imminent and recommended that students' study reading practices must be regulated and monitored at institutional level to assist students in effective time management in an environment full of co- and extra- curricular distractions.
\end{abstract}

Keywords: Study reading, self communication, intrapersonal communication

DOI: $10.7176 /$ RHSS/9-1-04

\section{Introduction}

The primary responsibility of a student is to study if he is to attain the high standard in his course. The exercise becomes particularly more intensive and compelling at the tertiary level like the polytechnic where the student is expected to undertake researches and academic investigations. The ironic fact, however, is that the higher institutions are full of distractive co-curricular and extra-curricular activities which students rather engage in so that they will not just 'pass through the institution', but also for 'the institution to pass through them'.

Study reading is an intensive, time engaging activity. It involves what Robinson (1970) describes as SQ3R which is a five-stage technique to aid reading comprehension. SQ3R stands for: Survey - Question - Read Recall and Review.

Survey: Examine the whole before you read the parts - survey the book first, then the chapter, then the paragraph. Also look at the title, headings, and subheadings, captions under pictures, charts, graphs or maps, introductory and concluding paragraphs and any summaries.

Question: Ask yourself: Why are you reading this? What do you already know? What do you want to know? What is new or interesting about this material? Does this support / supplement/contradict what I already know? Try turning the title, headings, and/or subheadings into questions.

Read: Skim read at the first reading, looking for the main ideas and general structure of the text. Only then read for the purpose of making notes on the key points. Look for answers to the questions you first raised. Reduce your speed for difficult passages - stop and re-read parts which are not clear. Read only a section at a time and recite after each section.

Recall: Can I recall the key points without re-reading the text? Recall helps you to concentrate, and to make your reading active rather than passive. Orally ask yourself questions about what you have just read and/or summarize, in your own words, what you read. Take notes from the text but write the information in your own words. Underline/highlight important points you've just read. Use the method of recitation which best suits your particular learning style but remember, the more senses you use the more likely you are to remember what you read.

Review: Look back at the text to check your recall. Have you missed anything of importance?

In its Study Skills Website the Faculty of Humanities of the University of Manchester (2001) released the following plan of action for their students interested in study reading. It is interesting to note that the plan covers not only the weekdays, but also weekends.

Day One: After you have read and recite the entire chapter, write questions for those points you have highlighted/underlined in the margins. If your method of recitation included note-taking in the left hand margins of your notebook, write questions for the notes you have taken.

Day Two: Page through the text and/or your notebook to re-acquaint yourself with the important points. Cover the right hand column of your text/note-book and orally ask yourself the questions in the left hand margins. Orally recite or write the answers from memory. Make "flash cards" for those questions which give you 
difficulty. Develop mnemonic devices for material which need to be memorized.

Days Three, Four, and Five: Alternate between your flash cards and notes and test yourself (orally or in writing) on the questions you formulated. Make additional flash cards if necessary.

Weekend: Using the text and notebook, make a Table of Contents — list all the topics and sub-topics you need to know from the chapter. From the Table of Contents, make a Study Sheet/ Spatial Map. Recite the information orally and in your own words as you put the Study Sheet/Map together. Now that you have consolidated all the information you need for that chapter, periodically review the Sheet/Map so that at test time you will not have to cram.

The implication of this study reading plan is that in whatever he does every day of the week a student is expected to engage in one study activity or the other. Only students who are sufficiently self-motivated can engage in these kinds of study reading exercise. For him to succeed in his studies therefore, a serious-minded student must incorporate into his daily activities a significant dose of his academic pursuits and reading plans. One effective way to exhibit and demonstrate such intensive study reading exercise is through the practice of self-communication otherwise referred to as intrapersonal communication defined by Wikipedia as 'a communicator's internal use of language or thought'.

Lister (2016) affirms that developing effective intrapersonal communication takes discipline and a willingness to slow down your day enough to hear your own thoughts. With time, an effective intrapersonal communication strategy can help you better organize your daily tasks and remain calm in hectic situations. Weisman (2014) explains that there is only one person with whom we communicate 24 hours a day, 7 days a week, 52 weeks a year, every year of our life - ourselves. Mastering communication with ourselves determines our quality of life as it determines our ability to experience life as we would like. Through the process of selfcommunication, a student can convert his daily activities and chores to a study session. Even when he is involved in other programmes, he is still engaged intra-personally in his study assignment.

Tibetan and Polars (2012) identify three levels of intrapersonal communication as follows:

- Internal Discourse: thinking, concentrating and analyzing within one self in form of day dreaming, praying, or meditating.

- Solo-vocal: that communication which takes place while one shouts loudly for clarifying one-self or rehearsing, or talking to one-self to remind one-self of what to do.

- Solo-written communication: It deals with writing for ones-self and not for others. Like writing notes for your future use.

Ruesch and Bateson (2016) work to further breakdown the three levels of intrapersonal communication to encompass the following seven traits which this study believed every studious student should exhibit on a regular basis in relation to their study reading:

- Speaking aloud - repeating what one hears, speaking what one thinks, reads or hears.

- Internal monologue at a conscious or semi-conscious level.

- Doodling - Writing one's thoughts or observations unconsciously

- $\quad$ Making gestures while thinking

- $\quad$ Sense-making e.g. interpreting maps, texts, signs, and symbols

- Interpreting non-verbal communication e.g. gestures, eye contact

- $\quad$ Communication between body parts; e.g. "My stomach is telling me it's time for lunch."

Study reading skills are full of actions that ought to provoke in a serious-minded student series of selfcommunication activities irrespective of where he is or what he is doing. SQ3R actions like 'recall', 'question', and 'recite' are also expected to provoke such self communication and involuntary actions in students.

\section{Statement of the Problem}

In their paper on integrated study reading, Olajide, Adeosun, and Adeyeri (2017) observe that the common trend among majority of the students is to delay serious reading till few days to examination. According to them, this leads to ineffective time management and low academic achievement. This study was conducted to investigate the commitment of polytechnic students to study reading before and during examination as manifested in the nature and frequency of their self communication activities.

\section{Hypotheses}

The following three hypotheses were postulated

i. There will be high self-communication in study reading among students before examination and during examination

ii. There will be a significant relationship between students' self-communication in study reading before examination and during examination.

iii. There will be no significant difference between students' self-communication in study reading before 
examination and during examination.

\section{Design}

The study was ex post facto in design. The self-communication traits being investigated already existed in the research subjects. The study instrument was designed to elicit from the students their perception of the pattern of manifestation of the traits in their day-to-day self-communication activities

\section{Sampling Procedure and Study Sample}

Polytechnic students in Nigeria constituted the study population. In selecting the study sample the institutions were stratified into two, those in the Northern part of the country and those in the South. From the South the South-west was purposively selected. Four institutions from the South-west were selected based on stratified criterion of ownership. One each was randomly selected from federal and private institutions and two from stateowned institutions. From each of the four selected institutions, one hundred students were randomly selected to fill the questionnaire. A total of four hundred students of male and female genders made up the study sample.

\section{Procedure}

Self-Communication Questionnaire (SCQ) was adapted with modifications from Olajide and Olatipe (2017) and administered on four hundred randomly selected students of four polytechnics. It contained twenty-eight selfcommunication activities that reflected the seven traits identified by Ruesch and Bateson (2016). The respondents were required to indicate frequency of occurrence of identified traits - whether Always, Sometimes, Rarely; or Never - in their study reading. The questionnaire was administered twice to the same set of students long before the examination and during examination.

\section{Data Analysis}

The frequency counts of students' responses were taken and each response was scored as follows: Always - 3; Sometimes - 2; Rarely - 1, Never - 0. The mean score was calculated and interpreted as follows: 0-0.50 (Very Low); 0.51-1.00 (Low); 1.10-1.50 (Average); 1.51-2.00 (Above Average); 2.10-2.50 (High); and 2.51-3.00 (Very High). The tests of significance in the relationship and difference were conducted respectively using the correlation and t. test packages in the SPSS software.

\section{Presentation and Interpretation of Data}

Hypothesis 1: There will be high self-communication in study reading among students before and during examination.

Table 1: Mean and Rating of Students' Self-Communication in Study Reading

\begin{tabular}{|l|c|l|c|l|}
\hline & \multicolumn{2}{|c|}{ Before Examination } & \multicolumn{3}{|c|}{ During Examination } \\
\hline & $\begin{array}{c}\text { Mean } \\
\mathrm{N}=400\end{array}$ & Remark & $\begin{array}{c}\text { Mean } \\
\mathrm{N}=400\end{array}$ & \\
\hline Speaking aloud & 0.99 & Low & 1.70 & Above Average \\
\hline Internal monologue & 1.00 & Low & 1.51 & Above Average \\
\hline Doodling & 1.35 & Average & 1.69 & Above Average \\
\hline Making Gestures while thinking & 0.99 & Low & 1.77 & Above Average \\
\hline Sense-making & 1.30 & Average & 1.66 & Above Average \\
\hline Interpreting non-verbal communication & 0.72 & Low & 1.60 & Above Average \\
\hline Communication between body parts & 1.39 & Average & 1.79 & Above Average \\
\hline Self Communication & $\mathbf{1 . 1 4}$ & Average & $\mathbf{1 . 6 7}$ & Above Average \\
\hline
\end{tabular}

Table 1 shows low rating in four of the seven self-communication variables among students before examination. The other three were at average level. Self communication before examination was just average. However, during examination students' display of self communication in all the seven traits shifted to above average. Although aggregate self communication rating improved from average rating before examination to above average during examination, self communication in study reading among the students did not attain the anticipated high rating therefore, hypothesis one was rejected. There was no high self-communication in study reading among students before examination and during examination.

Hypothesis 2: There will be a significant relationship between students' self-communication in study reading before and during examinations. 
Table 2: Paired Sample Correlation and t. test

\begin{tabular}{|c|c|c|c|c|c|c|c|c|c|c|c|}
\hline \multicolumn{5}{|c|}{ Paired Samples Correlation } & \multicolumn{7}{|c|}{ Paired Samples Difference } \\
\hline & $\mathrm{N}$ & Mean & $\mathrm{r}$ & Sig. & $\begin{array}{l}\text { Mean } \\
\text { Diff. }\end{array}$ & SD & SEM & $\begin{array}{r}95 \\
\text { Inter } \\
\end{array}$ & $\begin{array}{l}\text { onf. } \\
\text { of Diff }\end{array}$ & df & $\mathrm{t}$ \\
\hline $\begin{array}{l}\text { Before } \\
\text { Examination }\end{array}$ & 7 & 1.1057 & & & & & & Lower & Upper & & \\
\hline $\begin{array}{l}\text { During } \\
\text { Examination }\end{array}$ & 7 & 1.6743 & .46 & 298 & -.5686 & 2196 & 08299 & -.7717 & -.3655 & 6 & -6.851 \\
\hline
\end{tabular}

The paired samples correlation in table 2 shows a low positive relationship between the students' self communication practices before and during the examination. However, with p. value higher than .05 , the relationship is not significant. There was no significant relationship between students' self-communication in study reading before examination and during examination therefore hypothesis two was rejected.

Hypothesis 3: There will be no significant difference between students' self-communication in study reading before examination and during examination.

The paired sample difference in table 2 shows that the mean difference of -.5686 between students' self communication displays before and during examination is significantly big enough at 95 per cent confidence interval $(p<0.5)$. The $t$. value of -6.851 is less than .05 implying that the difference is quite significant therefore hypothesis two is rejected. There was a significant difference in the mean values of students' self communication practices before examination and during examination.

\section{Discussion}

The findings of this study tend to show the internal focus of the students in their day-to-day activities before examination and during examination. The predominantly low/average self communication activities related to study reading before examination tend to confirm Olajide, Adeosun, and Adeyeri's (2017) observation that students delay serious reading till few days to examination. McPherson (2016) emphatically declares that reading actively involves thinking about what you are reading, asking yourself questions about it, and trying to relate it to the information you already know. Reading effectively for information or instruction, unlike reading a story, needs to be a very active process, for comprehension is far more difficult than it is in the familiar format of a story.

A situation where a student in a tertiary institution rarely_or never performs the following intracommunication activities before examination especially as they relate to study reading leaves so much to be desired:

- Unconsciously drawing a diagram or an image in the air with an imaginary pencil

- A voice within me waking me up from sleep to take a specific action

- $\quad$ Trying to recollect what I seem to have forgotten

- Making gestures while thinking on an issue even when no one is watching

- Trying to interpret within myself the sign or symbol I saw in the dream

- Unconsciously writing something in the air with an imaginary pen

It can be safely concluded that though that student had been reading he had actually not been studying. Study reading involves recalling and recitation and these exercises are expected to go on from time to time in the student's sub-consciousness.

Studying is an intensive reading exercise which Olajide and Faniran (2012) say is done with attention to details and analyses especially when one is aware that the material will later have to be recalled, discussed and evaluated. Constant analysis of a study text is expected to provoke intrapersonal communication traits such as 'trying to recollect what I seem to have forgotten', 'unconsciously drawing a diagram or writing in the air with an imaginary pen', or 'making gestures while thinking on an issue'. Students who engage in these selfcommunication acts before the onset of examinations but which are not in relation to their study reading and other academic programmes cannot be said to be dedicated to their studies.

In the same vein, Jones and Fernyhoug (2007) posit that our ability to talk to ourselves and think in words is a major part of the human experience of consciousness. Regular self-communication is a proof of student's consciousness of his academic assignments. An actively conscious student should frequently experience 'a voice within me waking me up from sleep to take a specific action'. And this action should not be unrelated to his academic studies like reading, tutorial and group discussion, writing an assignment, demonstrating a practical activity and so forth.

A higher value recorded in the self communication variables during examination implied that the students always or sometimes engaged in the following, among others:

- Making frantic efforts to get something to help me remember what I have forgotten

- Trying to recollect what I seem to have forgotten 
- Though not audibly, one mind of me saying what I'm doing is wrong while another is saying it is right

- Something in me telling me that where I am is not where I should be

- Something in me telling me that whom I am associating with is not whom I should be close with

- A voice within me waking me up from sleep to take a specific action (to read)

This certainly must always be the case because the students had waited till examinations were very close before they began to read late into the night or to look for whom to approach for assistance in difficult subject areas. Cybernetic lapse is what usually followed in that they forgot what they had read and therefore engaged in frantic efforts to remember or get somebody or something to remind them. This tended to lead many of them to engage in cheating to achieve their aims.

A popular maxim has it that readers are leaders. Aina, Ogungbemi, Adigun, and Ogundipe (2011) emphasize that students with poor reading skills receive poor grades at school, get easily distracted and frustrated, have behavior problems, seem to dislike school, and often fail to develop to their full potential. This must explain why a higher proportion of graduating students usually finishes with lower grades. Far less in number of students population graduate with distinction or second class upper grade. In most cases too, students' standard of performances in semester examinations fall short of outstanding. A larger proportion of the students often score far below the excellent mark of seventy out of one hundred marks obtainable.

Rubin (2002) also declares that students with poor reading habits have a higher chance of anti-social behavior. He posits that 'delinquency; school violence, bullying, hacking computers, and even examination malpractices have a correlation with poor reading habits ... good reading habits help develop a steady and constructive mind'. This must be a plausible explanation to the recurring problems of students' unrest and examination mal-practices in the institutions.

\section{Conclusion and Recommendation}

From this study, it could be safely concluded that academic study reading were not significantly reflected in the thoughts and self-communication habits of a good number of the students before examination. The implication, as it has been surmised, might be that not much of serious reading is going on in the polytechnics especially when examinations are not too close thus exposing the institutions to the risks of anti-social behaviours, violence, and examination mal-practices among the students. It would therefore be a most welcome development for institutions to design a plan of action that would promote study reading among the students. A recommendation at this juncture is the practice of integrated study reading which in their recent study, Olajide, Adeosun and Adeyeri (2018) discovered to have significant effect on students' time management and academic success mindset. It assisted in training the students to cultivate a lifestyle of effectiveness and efficiency whereby students learn to spend their time doing things right and doing right things.

Seen in the light of time management matrix postulated by Covey (2003), through the practice of integrated study reading the students learnt to place study reading in quadrant 2 meant for important but not urgent tasks. This implies that it helps the students to overcome the attitudinal problem to reading identified by Issa et.al (2012). According to their findings, some of the things the study sample did 'more often' during treatment included regular and punctual lecture attendance; visiting the library to borrow books and journals to read; timely submission of assignments; reading beyond course books; joining and participating in organized group discussions; approaching course lecturers for clarifications on difficult concepts; reading ahead to prepare for possible impromptu tests; and enjoying close rapport with course lecturers on academic matters.

The libraries must be stocked with adequate and relevant books and made more conducive to reading. Lecturers must give students more take-home assignments that will send them to the library and administer regular tests that will require students to recall and recite what they have read. Where possible, students may be asked to submit their jottings for inspection by the lecturer. To encourage the students to source online reading materials, institutions must provide free or subsidized access to internet.

Series of orientation talks and seminars on the values of time management and academic success mindset must be organized by the institutions. Students with very high sense of time management and academic success mindset will have the tendency to be more focused on their study reading activities; will not mind to be driven hard by the lecturers by way of regular tests and assignments; and will thus benefit maximally from the practice of study reading

\section{References}

Aina, A.J, Ogungbemi, J.I., Adigun., J.A. \& Ogundipe, T.C. (2011): Poor Reading Habits among Nigerians: The Role of Libraries - http://unllib.unl.edu/LPP/ Retrieved 13-11-2016

Jones, S. R., \& Fernyhoug, C. (2007): Thought as action: Inner speech, self-monitoring, and auditory verbal hallucinations. Consciousness and Cognition 16, 391-399.

Lister, J. (2016): Effective Intrapersonal Communication Demand Media http://smallbusiness.chron.com/effective-intrapersonal-communication-36895.html . Retrieved 13-01- 
2016

McPherson, F. (2016): Reading for Study http://www.mempowered.com/study/reading Retrieved October 2016

Microsoft Corporation (2009): Microsoft Encarta Dictionary

Nssien, F.U. (2007) Reading Habits and Skills in F.E. Etim and F.U. Nssien (eds.) Information Literacy for Library Search, Uyo: Abaam Publishing, pp 90 - 105.

Olajide, J.L; Adeosun, T.H; \& Adeyeri, L.O. (2018): Effect of Integrated Study Reading on Polytechnic Students' Time Management and Academic Achievement. Journal of Education and Practice 9 (14) ISSN 2222-288X online pp 98-104

Olajide, J.L. \& Faniran, O.A. (2012): Effective Communication in English $3^{\text {rd }}$ Edition; Ilesa, Glorious Prints

Olajide, J.L \& Olatipe, S.O (2017): Self-Communication in Study Reading among Polytechnic Students in Nigeria in Folajogun \& Adegbile eds (2017) Issues in Curriculum and Language Education - Book of Readings in Honour of Prof. M. A. Araromi, Institute of Education, University of Ibadan

Robinson, F. P. (1970): Effective Study (4th ed.), Harper \& Row, New York, NY

Rubin, Dorothy (2002): Diagnosis and Correction in Reading and Guiding Reading Instruction. 4th ed. Boston: Allyn and Bacon.

Ruesch, J \& Bateson, G.: Communication (2016): The Social Matrix of Psychiatry, cited in Wikipedia Interpersonal Communication Retrieved in October 2016

The University of Manchester (2001) Study Reading Faculty of Humanities Study Skills Website http://www.humanities.manchester.ac.uk/studyskills/essentials/reading/study_reading.html Retrieved in February, 2016

Tibetan Shepherd \&Tibetan Polars (2012): Differentiate between intrapersonal and interpersonal Communication; compare their merits \& demerits. https://victimofred.wordpress.com/2012/09/17 Retrieved October 2016

Weisman, S. (2014): Self-Communication is the Foundation of Success http://www.personalbrandingblog.com/ Retrieved on 13-01-2016

Wikipedia, the free encyclopedia https://en.wikipedia.org/wiki/Intrapersonal_communication 